\title{
Methodology Formulation for Generating MANET Results for Energy Consumption and Packet Distance Considerations in Ubicomp MANETs.
}

\author{
M. Kaleem GALAMALI, Assoc. Prof Nawaz MOHAMUDALLY
}

\begin{abstract}
Reliability is among the key features that must be addressed in all pieces of technology in order to undertake wide deployment and integration of the technology in everyday life [1]. This also affects ubicomp whereby knowledge of trends of metrics formulated will serve towards constructing reliability frameworks. Quite some work has been conducted based on simulator in this direction [14-65] and new metrics for ubicomp have been laid forward. In former papers [66-68], it was mentioned that the methodology devised for producing the results concerning the sixteen metrics was also novel and necessitated implementing components not existent so far. The methodology was split into five steps.
\end{abstract}

In this paper, the fourth step concerning methodology for generating MANET results for ubicomp MANETs, along with its design and implementation particularities is elaborated. The MANET nodes are assumed as behaving properly and no concern for nodes being supplied as infrastructure or not is taken.

The results of this study may serve towards more refined methodology formulation for generating MANET results for "Energy Consumption" and "Packet Distance" considerations in ubicomp MANETs. This approach may also be adopted for generating many off-the-shelf such components, which would in turn facilitate further empirical research activities. This paper is a retrospective delivery of the fourth of five parts of the methodology designed, over which previous work [14-65] was built over. It also follows the delivery of the first three parts of the methodology [66-68].

Key terms: Ubicomp- Ubiquitous Computing, CBR- Constant Bit Rate, MANET- Mobile Adhoc Network, NS2- Network Simulator 2.

M. Kaleem GALAMALI,

University of Technology Mauritius (student)

Mauritius

Assoc. Prof Nawaz Mohamudally

University of Technology Mauritius,

Mauritius

\section{Introduction}

A lot of future ubicomp upgrades will be based on probabilistic metrics-based adaptations to provide optimal performance in ubicomp topographies. To help in this aim, knowledge about applicable metrics and their theoretical trends will prove useful and such work have been provided before [14-65]. It would also be beneficial to know the novel methodology developed, including its pertaining design concerns. As mentioned in prior three papers [66-68], the methodology has been split into five components.

i. Tracking of exact positions of ubicomp MANET nodes.

ii. MANET Route formulation and tracking nodes energy expenditure.

iii. Processing of MANET_Routes_Packets_Per_CBR

iv. MANET Results Generations.

v. Automated Extraction of Data From Files

The work published precedingly [14-65] were based on application of exact location-awareness at per packet transmission level. The first three parts have been developed in previous papers [66-68]. The fourth part of the methodology mentioned above, is illustrated as a key contribution of this paper, is built over the first three parts. Again, precision is brought forward that simulator NS2 has been used with a topography of 300 x $300 \mathrm{~m}^{2}$ with TCL as programming language. The rest of this paper is organised as follows: section 2: Experimental set-up used, section 3: Methodology Details and Section 4: Conclusion and References.

\section{Experimental Set-Up Used.}

The same experimental set-up described in previous papers [66-68] is applied here again.

\section{Methodology Details.}

This concerns programs to gather summarised tabular results from data obtained in previous paper [68] from which section 3.1 is followed.

\subsection{Energy Consumption Considerations.}

\subsubsection{Need for Result of Previous Work and Attempts for Optimisation.}

Results needed here, required comparison against data gathered in "Per_CBR_streams_track.dat" obtained in previous work [2]. This file was opened and data required from each record is extracted and assigned to appropriate array variables. This gives advantage of rapidity for further processing as the file consisting of 6300 records and going through it is visibly time 
consuming. Having assigned values to arrays meant that the need for going through the file is only once. Whenever any information was required, it could then be retrieved from appropriate indices from appropriate array variables.

\subsubsection{Identifying Metrics to Analyse.}

The metrics over which the empirical study could proceed further have been identified as:

i. Percentage energy saved by sender node.

ii. Percentage energy saved by overall nodes participating in a CBR transmission.

iii. Sender Fairness Proportion.

Fairness proportion is that value obtained when overall energy consumed for a CBR is divided equally by all nodes present in the topography. It is the mean energy to be consumed by each node if the transmission task was equally shared by all nodes.

iv. Overall fairness proportions.

v. Maximum fairness proportion being noted.

vi. Minimum fairness proportion being noted.

vii. Overall energy consumption ratio summary, i.e. the measure of how many nodes and corresponding percentages are achieving what ratios.

viii. Maximum ratios noted, i.e. the measure of number of CBRs and corresponding percentages achieving maximum ratio values compared against sender.

ix. Minimum ratios noted.

x. Overall fairness ratios, i.e. ratio of number of nodes spending less than sender node against the sum of sender node plus number of nodes spending equal or more than sender node.

xi. Overall node savings less node-to-node energy savings.

This will be the measure of extra savings achieved against node-to-node energy savings.

Sender node savings less node-to-node energy savings, i.e. the measure of extra savings being effected by sender only compared to node-to-node energy savings.

\subsubsection{Methodology Sequence Adopted.}

For each node number, a file
"energy_consideration_summary.dat" is to be derived with information towards reaching the above 12 metrics calculated. Each record would be the summary record for each CBR. The work is thus done in nested loops as follows:

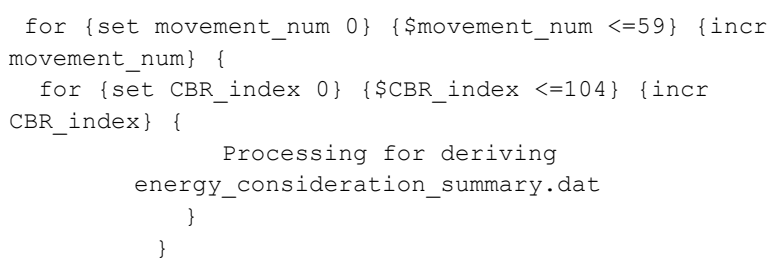

Previous to the above loop, the following is initialised for $\{$ set $i 0\} \quad\{i<=104\}$ incr $i\}\{$ set num_nodes_ratio(\$i) 0

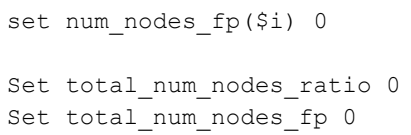

The above four initialised variables defined are also processed during the single execution of the nested loop above, to increase speed of execution.

To have a workable/observable number of records, the metrics defined are rounded as:

$>$ Rounded to nearest unit: overall energy savings, overall less node-to-node energy savings, sender energy savings, sender less node-to-node energy savings.

$>$ Rounded to nearest 1 d.p: overall fp, overall ratio, max fp, max ratio, min fp, sender fp.

$>$ Rounded to nearest 2 d.p: min ratio, overall fairness ratio.

A record in file "energy_consideration_summary.dat" consists of the CBR number, the BRE value and each of the metrics name followed by their unrounded value.

Following the initialisation of the four variables, overall $\mathrm{fp}$ and overall ratio are compiled with the following pieces of data: actual $\mathrm{fp}$, num_nodes with corresponding $\mathrm{fp}$, total number of nodes, corresponding $\%$ of nodes, num_nodes less than or equal to the actual $\mathrm{fp}$, num_nodes greater than or equal to the actual fp. For each of these two metrics, a separate file is saved for graph plottings.

For each of the metrics in section 3.1.2 of this paper except metrics number (iv) and (vii), the file energy_consideration_summary.dat is opened for the processing calculation.

For each node number, the processing is quite rapid, each taking about 2 minutes. There is no big need for monitoring progresses as suspending program execution is not envisaged here. Overall, this processing is very rapid and can be applied over complete data for each node numbers explained in previous paper [68] as and when they are ready. Here also, results are compiled including the following: actual value, corresponding number of nodes and percentage, corresponding number of nodes less than or equal actual value, corresponding number of nodes greater or equal and respective percentages.

Loop execution for node numbers 7 until 56 could be attempted but is preferably avoided since it would have required additional testings which do not enhance the value here, and data for all node numbers are not all available at once. These data are ready in a piecemeal fashion. 


\subsubsection{Folder Structure Needed to Save Results.}

A parent folder named "MANET_Results_gen" is created with a subfolder "Energy_considerations" containing 50 subfolders named node_num_7, node_num $\_8, \ldots$. Until node_num_56, whereby in each 13 output files will be stored.

\subsubsection{Storage Requirements.}

The storage requirements are expected to be smaller than previous files since mostly summary files are being dealt with. Need for assistance from external hard disk is not felt here. The detailed storage space needed here are as follows in Table 1 with headings $\mathrm{A} \rightarrow$ node_number, $B \rightarrow$ Storage size.

\begin{tabular}{|c|c|c|c|}
\hline A & B & A & B \\
\hline 7 & $4.7 \mathrm{MB}$ & 32 & $7.5 \mathrm{MB}$ \\
\hline 8 & $5.5 \mathrm{MB}$ & 33 & $7.5 \mathrm{MB}$ \\
\hline 9 & $6.1 \mathrm{MB}$ & 34 & $7.6 \mathrm{MB}$ \\
\hline 10 & $5.5 \mathrm{MB}$ & 35 & $7.7 \mathrm{MB}$ \\
\hline 11 & $5.6 \mathrm{MB}$ & 36 & $7.8 \mathrm{MB}$ \\
\hline 12 & $5.7 \mathrm{MB}$ & 37 & $7.9 \mathrm{MB}$ \\
\hline 13 & $5.8 \mathrm{MB}$ & 38 & $8.1 \mathrm{MB}$ \\
\hline 14 & $5.9 \mathrm{MB}$ & 39 & $8.0 \mathrm{MB}$ \\
\hline 15 & $6.0 \mathrm{MB}$ & 40 & $8.1 \mathrm{MB}$ \\
\hline 16 & $6.1 \mathrm{MB}$ & 41 & $8.2 \mathrm{MB}$ \\
\hline 17 & $6.1 \mathrm{MB}$ & 42 & $8.3 \mathrm{MB}$ \\
\hline 18 & $6.2 \mathrm{MB}$ & 43 & $8.4 \mathrm{MB}$ \\
\hline 19 & $6.3 \mathrm{MB}$ & 44 & $8.5 \mathrm{MB}$ \\
\hline 20 & $6.4 \mathrm{MB}$ & 45 & $8.5 \mathrm{MB}$ \\
\hline 21 & $6.5 \mathrm{MB}$ & 46 & $8.6 \mathrm{MB}$ \\
\hline 22 & $6.6 \mathrm{MB}$ & 47 & $8.9 \mathrm{MB}$ \\
\hline 23 & $6.7 \mathrm{MB}$ & 48 & $8.8 \mathrm{MB}$ \\
\hline 24 & $6.8 \mathrm{MB}$ & 49 & $8.9 \mathrm{MB}$ \\
\hline 25 & $6.9 \mathrm{MB}$ & 50 & $9.0 \mathrm{MB}$ \\
\hline 26 & $6.9 \mathrm{MB}$ & 51 & $9.1 \mathrm{MB}$ \\
\hline 27 & $7.0 \mathrm{MB}$ & 52 & $9.2 \mathrm{MB}$ \\
\hline 28 & $7.1 \mathrm{MB}$ & 53 & $9.3 \mathrm{MB}$ \\
\hline 29 & $7.2 \mathrm{MB}$ & 54 & $9.3 \mathrm{MB}$ \\
\hline 30 & $7.3 \mathrm{MB}$ & 55 & $9.4 \mathrm{MB}$ \\
\hline 31 & $7.4 \mathrm{MB}$ & 56 & $9.6 \mathrm{MB}$ \\
\hline
\end{tabular}

Table 1: Energy Consumption Considerationsstorage space

\subsubsection{Program Optimisation.}

The expected sections that could cause delay in execution had already been identified and explained in section 3.1.1 of this paper and no further optimisation is felt necessary since the program completion time for each node number is satisfactory.

\subsubsection{Major Problems Encountered.}

The program as described in section 3.4.1.3 has worked only for node number 7 . For node number 8 , a big problem was noticed since the values of ratios increased drastically. Certain values were greater than 20 million. An initial attempt of increasing loop range from $0-100000$ to $0-20$ million in the initialisation section failed with memory allocation error (not enough RAM memory to sustain operation).
This problem was affecting data gathering for 2 sections:
i.
ii.
Energy_consideration_ratio_summary
Assembling max_ratio_summary.

These two sections were initially commented to test if remaining sections work correctly, which was the case.

To solve this problem, a serious program redesign was important. It was noticed that in initialisation loop described in section 3.1.3 of this paper, not all values were needed in program execution. It was hence decided to initialise values of ratios as and when they were discovered and confirmed to be new. The number of CBRs corresponding to the discovered ratios was incremented accordingly. The newly discovered ratios were stored in an array is subjected to a bubble sort to arrange the ratios discovered in ascending order. This process was implemented for assembling max_ratio_summary. It worked though bubble sorting took a perceptible amount of time. It was then applied for energy_consideration_ratio_summary. Here, for node number 8 , about 12000 new ratios were discovered and bubble sorting took long but overall, the whole process could be completed in about 7 minutes. For larger node numbers, the sorting was done with increasing number of values and took longer time but overall, the process has been successful. For node number 15 , time taken is 20 minutes; for node number 21 , time is 35 minutes; for node number 28 , it is 45 minutes. (Mostly, when the program were launched, other activities were being carried out in parallel: Studying gnuplot, performing certain graphical plots, writing next programs to run etc.)

\subsection{Packets Per Distance Considerations.}

\subsubsection{General Design Guidelines.}

The processing required here is relatively small to gather the summary of number of packets being sent over each distance rounded in metre.

Minimum distance of a transmission is $0 \mathrm{~m}$ (i.e. 0 until less than $0.5 \mathrm{~m}$ ). The maximum distance could be considered as the diagonal distance (around $424 \mathrm{~m}$ ). Correspondingly the following is initialised.

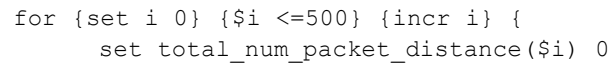

For each node number 7 until 56, a file "pkts_per_dist_summary.dat" is created. The program is run in a nested loop as follows:

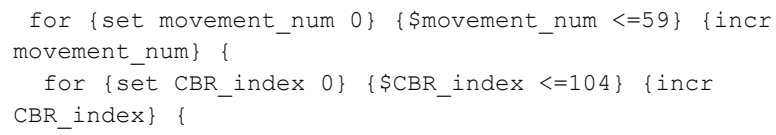


Proc. of The Seventh Intl. Conf. On Advances In Computing, Control And Networking - ACCN 2017

Copyright (C) Institute of Research Engineers and Doctors, USA .All rights reserved. ISBN: 978-1-63248-134-4 doi: 10.15224/ 978-1-63248-134-4-16

Processing pkts per distance

As processing pkts per distance, the files "summary_num_pkts_dist_CBR_\$i” are opened successively and the info about total_num_packets corresponding to each meter distance is updated. The corresponding information for num packets less_than_or_equal_to and greater_than_or_equal_to each distance and corresponding percentages are saved. An example record is

dist $(m)$ : 0 total_num_pkts 4152834 of_total 422948945 rep_o_of $0.98187 \overline{5} 956 \overline{6} 8314054<=4152 \overline{8} 34 \%<=$

$0.9 \overline{8} 1 \overline{8} 7595668314054>=422948945 \%>=100.0$

Saving is done for a record only if value of total_num_packets_distance (\$i) is greater than 0 . This is to save on storage space and facilitate data analysis.

For each node number, the processing is again quite rapid, each taking about 2 minutes. Again, no big need for monitoring progresses is felt and program execution is satisfactorily rapid, involving no anticipated suspension.

\subsubsection{Folder Structure Needed.}

Inside the folder "MANET_Results_gen" explained in section 3.1.4 of this paper, a subfolder "distance_pkt_sent_considerations" is created inside which 50 sub folders corresponding to node_numbers 7 until 56 is created. Each node_number subfolder will host 1 file "pkts_per_dist_summary.dat".

\subsubsection{Storage Requirements.}

The output files are quite small as seen in the following table 2 with headers $\mathrm{A} \rightarrow$ node number, $\mathrm{B} \rightarrow$ Storage Size (in KB).

\begin{tabular}{|c|c||c|c|}
\hline A & B & A & B \\
\hline 7 & 894.4 & 32 & 892.4 \\
\hline 8 & 890.1 & 33 & 894.1 \\
\hline 10 & 890.8 & 34 & 893.0 \\
\hline 11 & 889.6 & 35 & 893.0 \\
\hline 12 & 889.9 & 36 & 902.9 \\
\hline 13 & 890.0 & 37 & 904.0 \\
\hline 14 & 891.3 & 38 & 903.3 \\
\hline 15 & 890.6 & 39 & 904.9 \\
\hline 16 & 893.0 & 40 & 907.1 \\
\hline 17 & 893.2 & 41 & 905.4 \\
\hline 18 & 890.8 & 42 & 903.5 \\
\hline 19 & 891.5 & 43 & 907.4 \\
\hline 20 & 891.4 & 44 & 904.4 \\
\hline 21 & 891.8 & 45 & 901.7 \\
\hline 22 & 893.7 & 46 & 903.4 \\
\hline 23 & 892.4 & 47 & 903.7 \\
\hline 24 & 895.0 & 48 & 904.2 \\
\hline 25 & 896.0 & 49 & 903.5 \\
\hline 26 & 896.6 & 50 & 902.6 \\
\hline 27 & 891.8 & 51 & 901.7 \\
\hline 28 & 892.3 & 52 & 900.2 \\
\hline & & 900.6 \\
\hline
\end{tabular}

\begin{tabular}{|c|c||c|c|}
\hline 29 & 892.9 & 54 & 901.3 \\
\hline 30 & 892.0 & 55 & 900.0 \\
\hline 31 & 890.8 & 56 & 901.1 \\
\hline Overall Space Needed here & 44847.7 \\
\hline
\end{tabular}

Table 2: Packets_Per_distance - Storage Space

\subsubsection{Other Metrics Studied.}

Three additional topics of study have been identified:

i. Number and percentage CBRs experiencing minimum distance from each unit of 0 until $450 \mathrm{~m}$.

ii. Number and percentage CBRs experiencing maximum distance from each unit of 0 until $450 \mathrm{~m}$.

iii. Number and percentage CBRs experiencing range distance between minimum and maximum distance from each unit of 0 until $450 \mathrm{~m}$.

These required values are gathered during the running of program as described in section 3.2 of this paper and a one-line summary corresponding to each movement and CBR index is saved in a file "dist_range_summary.dat".

For each of the three topics of study identified above, the file "dist_range_summary.dat" is opened for reading and appropriate processing is performed to assemble tabular data which includes values for the "less_than_or_equal_to", the also necessary value of "greater_than_or_equal_to" and percentages. Each of these three processing is implemented in one file which are called in sequence at the end of the loop described in section 3.2 of this paper after closing files opened for writing.

It results that 4 tabular data files are generated in a single round of program execution.

\subsubsection{Execution Times Noted.}

One round of execution is effected for each node number. The times taken for initial rounds for node numbers 7 and 8 were noted at roughly 2 minutes (very rapid). The time taken increases gradually for increasing node numbers; for node number 25 , a time of roughly 5 minutes is noted. Overall, this process of summary gathering is extremely rapid as compared to programs described in section 3.3.

\subsubsection{Major Problems Encountered.}

A major problem in processing results has been found in total number of packets as from node_num 36 and onwards in files "pkts_per_dist". Indeed, as number of nodes increases, there is a tendency for total number of packets in circulation to increase. At a point, it becomes negative, which is a computational malfunction dealing with limits of TCL. 
After investigation, it was found that the maximum integer allowable in TCL (programming Language used in NS-2) is $2^{31}-1$ (2 147483647 ), since a maximum of 32 bits is used, with one bit for the sign [Cleverl, 2005]. The total number of packets were exceeding this maximum value for successive node_num as from 36 .

The impact must also be analysed in the results. The consequence was that the required percentages and cumulative data were being garbled. Percentages like $167.2034 \ldots$ (to $12 \mathrm{~d}$.p) could be found. The number of packets for each distance in each record was not garbled.

A solution was devised using simple mathematics concepts to prevent data from exceeding the limit of $2^{31}-1$. Usually,

$$
\sum x=x 1+x 2+x 3+\ldots . \quad \text { Where } x 1, x 2, x 3, \ldots .
$$

are data from successive records in file

Here, $\mathrm{x}$ will be number of packets for each recorded distance. The problem is though each $\mathrm{x}$ value is correct, the sum will exceed the maximum limit.

What is done is simply that each data retrieved is multiplied by a multiplication factor of 0.1 after which the results are added.

$$
\begin{aligned}
& \mathrm{y} 1=\mathrm{x} 1 * 0.1 \\
& \sum \mathrm{y}=\mathrm{y} 1+\mathrm{y} 2+\mathrm{y} 3
\end{aligned}
$$

Here, $\sum y$ will be smaller ( reduced to one tenth of the original $\sum \mathrm{x}$ ), and hence may not exceed the maximum limit. To calculate the percentage represented by $x 1$, the process is simple.

$$
\text { Percentage } \mathrm{x} 1=\left[[\mathrm{x} 1 * 0.1] / \sum \mathrm{y}\right] * 100
$$

Hence, using the "pkts_per_dist" files and applying the above, described procedure, the problem could be solved and the corrected data saved in another file.

The solution is more fault tolerant, since in case $\sum y$ is also exceeding the max limit, the multiplication factor used here $(0.1)$ could be reduced to 0.01 or 0.001 (or lesser ) to make the work continue. This solution has been successfully applied as from node_num 36 onwards.

\section{Conclusion.}

This piece of investigation has delivered, to good levels of details, the formulation of a methodology and implementation of a method for generating MANET results for Energy Consumption and Packet Distance Considerations in ubicomp MANETs. TCL was the programming language used to implement the programs required. Processed data were stored and rounded to appropriate decimal places. Such a methodology with modifications/refinements may be used by other researchers embarking on empirical research in ubicomp to unveil new metrics. This methodology has been novel and such components were not pre-existing. This methodology has been the fourth of five components formulations over which empirical research [14-65] have been feasible; this study, however, remains a complete one standing on its own.

This methodology was designed without concern for nodes in the MANET being supplied as infrastructure or not and assuming that all nodes behave properly in the topography. The results of this study can serve towards better formulation of methodology for generating MANET results for Energy Consumption and Packet Distance considerations in ubicomp. Many off-the-shelf empirical components may also be generated for further research to be facilitated.

Further work identified remains developing the methodology for the last component identified in section 1 of this paper.

\section{References}

[1] M. Kaleem GALAMALI, Assoc. Prof Nawaz MOHAMUDALLY, Towards Dependable Pervasive Systems-A Position and Vision Paper, CEET 2014

[2] M. Kaleem GALAMALI, Assoc. Prof Nawaz MOHAMUDALLY, Model of Energy Savings achievable with Location-aware Node-to-Node Transmission in UbiComp , CEET 2014

[3] M. Kaleem GALAMALI, Assoc. Prof Nawaz MOHAMUDALLY, Model of Energy Savings achievable with Location-aware Node-to-Node Transmission in UbiComp Using Location Refresh Intervals, CEET 2014

[4] M. Kaleem GALAMALI, Assoc. Prof Nawaz MOHAMUDALLY, Model of Energy Savings achievable with Location-aware Transmission in UbiComp Using Relays, CEET 2014

[5] M. Kaleem GALAMALI, Assoc. Prof Nawaz MOHAMUDALLY, Mathematical modeling of need of exact number of relays to ensure seamless mobility in mobile computing, CEET 2014

[6] M. Kaleem GALAMALI, Assoc. Prof Nawaz MOHAMUDALLY, Modelling of need for multiple relays for ensuring seamless mobility, CEET 2014

[7] M. Kaleem GALAMALI, Assoc. Prof Nawaz MOHAMUDALLY, Investigation of prominence of placements of relays in a ubicomp topography,

[8] M. Kaleem GALAMALI, Assoc. Prof Nawaz MOHAMUDALLY, Model of energy savings achievable with location-aware transmission in ubicomp using optimised number of relays.

[9] M. Kaleem GALAMALI, Assoc. Prof Nawaz MOHAMUDALLY, Investigation of Prominence of Placements of Optimised Number of Relays in a Ubicomp Topography using Location-Aware Transmission, CEET 2015.

[10] M. Kaleem GALAMALI, Assoc. Prof Nawaz MOHAMUDALLY, Extending Node Battery Availability in Ubicomp with Location-Aware Transmission, CEET 2015.

[11] M. Kaleem GALAMALI, Assoc. Prof Nawaz 
MOHAMUDALLY, Extending Node Battery Availability in Ubicomp with Location-Aware Transmission using Location Refresh Intervals, CEET 2015.

[12] M. Kaleem GALAMALI, Assoc. Prof Nawaz MOHAMUDALLY, Extending Node Battery Availability in Ubicomp with Location-Aware Transmission using Uniformly Placed Relays, CEET 2015.

[13] M. Kaleem GALAMALI, Assoc. Prof Nawaz MOHAMUDALLY, Extending Node Battery Availability in Ubicomp with Location-Aware Transmission Using Optimally Placed Relays, CEET 2015.

[14] M. Kaleem GALAMALI, Assoc. Prof Nawaz MOHAMUDALLY, Model of Sender Node Energy Savings Achievable with Location-Aware MANET Transmission in Ubicomp. ACCN 2016

[15] M. Kaleem GALAMALI, Assoc. Prof Nawaz MOHAMUDALLY, Model of Overall Node Energy Savings Achievable with Location-Aware MANET Transmission in Ubicomp. ACCN 2016

[16] M. Kaleem GALAMALI, Assoc. Prof Nawaz MOHAMUDALLY, Model of Sender Node Extra Energy Savings Achievable in MANET Against Direct Node-to-Node Transmission Using Location-Aware Transmission in Ubicomp. ACCN 2016

[17] M. Kaleem GALAMALI, Assoc. Prof Nawaz MOHAMUDALLY, Model of Overall Node Extra Energy Savings Achievable in MANET against Direct Node-to-Node Transmission Using Location-Aware Transmission in Ubicomp. ACCN 2016

[18] M. Kaleem GALAMALI, Assoc. Prof Nawaz MOHAMUDALLY, Model of Energy Consumption Ratio Achievable in MANET Using Location-Aware Transmission in Ubicomp. ACCN 2016

[19] M. Kaleem GALAMALI, Assoc. Prof Nawaz MOHAMUDALLY, Model of Minimum Energy Consumption Ratio Achievable in MANET Using LocationAware Transmission in Ubicomp. ACCN 2016

[20] M. Kaleem GALAMALI, Assoc. Prof Nawaz MOHAMUDALLY, Model of Maximum Energy Consumption Ratio Achievable in MANET Using LocationAware Transmission in Ubicomp. ACCN 2016

[21] M. Kaleem GALAMALI, Assoc. Prof Nawaz MOHAMUDALLY, Model of Overall Energy Consumption Fairness Ratio Achievable in MANET Using Location-Aware Transmission in Ubicomp. ACCN 2016

[22] M. Kaleem GALAMALI, Assoc. Prof Nawaz MOHAMUDALLY, Model of Overall Energy Consumption Fairness Proportion Achievable in MANET Using LocationAware Transmission for Ubicomp, CEET 2016

[23] M. Kaleem GALAMALI, Assoc. Prof Nawaz MOHAMUDALLY, Model of Minimum Fairness Proportion Achievable in MANET Using Location-Aware Transmission for Ubicomp, CEET 2016

[24] M. Kaleem GALAMALI, Assoc Prof Nawaz MOHAMUDALLY, Model of Maximum Fairness Proportion Achievable in MANET Using Location-Aware Transmission for Ubicomp, CEET 2016

[25] M. Kaleem GALAMALI, Assoc. Prof Nawaz MOHAMUDALLY, Model of Sender Fairness Proportion Achievable in MANET Using Location-Aware Transmission for Ubicomp, CEET 2016

[26] M. Kaleem GALAMALI, Assoc. Prof Nawaz MOHAMUDALLY, Model of Distance Travelled by packets in MANETs using Location-Aware Transmission for Ubicomp, CEET 2016

[27] M. Kaleem GALAMALI, Assoc. Prof Nawaz MOHAMUDALLY, Model of Maximum CBR Distance Travelled by packets in MANETs using Location-Aware Transmission for Ubicomp, CEET 2016

[28] M. Kaleem GALAMALI, Assoc. Prof Nawaz MOHAMUDALLY, Model of Minimum CBR Distance Travelled by packets in MANETs using Location-Aware Transmission for Ubicomp, CEET 2016

[29] M. Kaleem GALAMALI, Assoc Prof Nawaz MOHAMUDALLY, Model of Range CBR Distance Experienced by Transmissions in MANETs using LocationAware Transmission for Ubicomp, CEET 2016

[30] M. Kaleem GALAMALI, Assoc. Prof Nawaz MOHAMUDALLY, Trend Analyses of Parameters of
Equations for Sender Node Energy Savings Achievable in ubicomp MANETs using Location-Aware Transmission, ACCN 2017

[31] M. Kaleem GALAMALI, Assoc. Prof Nawaz MOHAMUDALLY, Trend Analyses of Parameters of Equations for Overall Node Energy Savings Achievable in ubicomp MANETs using Location-Aware Transmission, ACCN 2017

[32] M. Kaleem GALAMALI, Assoc. Prof Nawaz MOHAMUDALLY, Trend Analyses of Parameters of Equations for Sender Node Extra Energy Savings Achievable in MANET against Direct Node-to-Node Location-Aware Transmission, ACCN 2017.

[33] M. Kaleem GALAMALI, Assoc. Prof Nawaz MOHAMUDALLY, Trend Analyses of Parameters of Equations for Overall Nodes Extra Energy Savings Achievable in MANET against Direct Node-to-Node Location-Aware Transmission, ACCN 2017.

[34] M. Kaleem GALAMALI, Assoc. Prof Nawaz MOHAMUDALLY, Trend Analyses of Parameters of Equations for Energy Consumption Ratio Achievable in Ubicomp MANET Using Location-Aware Transmission, ACCN 2017.

[35] M. Kaleem GALAMALI, Assoc. Prof Nawaz MOHAMUDALLY, Trend Analyses of Parameters of Equation for Minimum Energy Consumption Ratio Achievable in Ubicomp MANETs Using Location-Aware Transmission, ACCN 2017.

[36] M. Kaleem GALAMALI, Assoc. Prof Nawaz MOHAMUDALLY, Trend Analyses of Parameters of Equations for Maximum Energy Consumption Ratio Achievable in Ubicomp MANETs Using Location-Aware Transmission, ACCN 2017.

[37] M. Kaleem GALAMALI, Assoc. Prof Nawaz MOHAMUDALLY, Trend Analyses of Parameters of Equations for Overall Fairness Ratio Achievable in Ubicomp MANETs Using Location-Aware Transmission, ACCN 2017.

[38] M. Kaleem GALAMALI, Assoc. Prof Nawaz MOHAMUDALLY, Trend Analyses of Parameters of Equations for Energy Consumption Fairness Proportion Achievable in Ubicomp MANETs Using Location-Aware Transmission, CEET 2017

[39] M. Kaleem GALAMALI, Assoc. Prof Nawaz MOHAMUDALLY, Trend Analyses of Parameters of Equations for Minimum Fairness Proportion Achievable in Ubicomp MANETs Using Location-Aware Transmission, CEET 2017

[40] M. Kaleem GALAMALI, Assoc. Prof Nawaz MOHAMUDALLY, Trend Analyses of Parameters of Equations for Maximum Fairness Proportion Achievable in Ubicomp MANETs Using Location-Aware Transmission, CEET 2017

[41] M. Kaleem GALAMALI, Assoc. Prof Nawaz MOHAMUDALLY, Trend Analyses of Parameters of Equations for Sender Fairness Proportion Achievable in Ubicomp MANETs Using Location-Aware Transmission, CEET 2017

[42] M. Kaleem GALAMALI, Assoc. Prof Nawaz MOHAMUDALLY, Trend Analyses of Parameters of Equations for Packets Per Distance Achievable in Ubicomp MANETs Using Location-Aware Transmission, CEET 2017

[43] M. Kaleem GALAMALI, Assoc. Prof Nawaz MOHAMUDALLY, Trend Analyses of Parameters of Equations for Maximum CBR Distance Achievable in Ubicomp MANETs Using Location-Aware Transmission, CEET 2017

[44] M. Kaleem GALAMALI, Assoc. Prof Nawaz MOHAMUDALLY, Trend Analyses of Parameters of Equations for Minimum CBR Distance Achievable in Ubicomp MANETs Using Location-Aware Transmission, CEET 2017

[45] M. Kaleem GALAMALI, Assoc. Prof Nawaz MOHAMUDALLY, Trend Analyses of Parameters of Equations for Range CBR Distance Achievable in Ubicomp MANETs Using Location-Aware Transmission, CEET 2017

[46] M. Kaleem GALAMALI, Assoc. Prof Nawaz MOHAMUDALLY, Trend Analyses of Critical Values Obtained for Sender Node Energy Savings Achievable in Ubicomp MANETs Using Location-Aware Transmission, CEET 2017

[47] M. Kaleem GALAMALI, Assoc. Prof Nawaz MOHAMUDALLY, Trend Analyses of Critical Values 
Obtained for Overall Node Energy Savings Achievable in Ubicomp MANETs Using Location-Aware Transmission, CEET 2017

[48] M. Kaleem GALAMALI, Assoc. Prof Nawaz MOHAMUDALLY, Trend Analyses of Critical Values Obtained for Sender Node Extra Energy Savings Achievable in Ubicomp MANET Against Direct Node-to-Node LocationAware Transmission, CEET 2017

[49] M. Kaleem GALAMALI, Assoc. Prof Nawaz MOHAMUDALLY, Trend Analyses of Critical Values Obtained for Overall Nodes Extra Energy Savings Achievable in Ubicomp MANET Against Direct Node-to-Node LocationAware Transmission, CEET 2017

[50] M. Kaleem GALAMALI, Assoc. Prof Nawaz MOHAMUDALLY, Trend Analyses of Critical Values Obtained for Energy Consumption Ratio Achievable in Ubicomp MANETs Using Location-Aware Transmission Strategies, CEET 2017

[51] M. Kaleem GALAMALI, Assoc. Prof Nawaz MOHAMUDALLY, Trend Analyses of Critical Values Obtained for Minimum Energy Consumption Ratio Achievable in Ubicomp MANETs Using Location-Aware Transmission Strategies, CEET 2017

[52] M. Kaleem GALAMALI, Assoc. Prof Nawaz MOHAMUDALLY, Trend Analyses of Critical Values Obtained for Maximum Energy Consumption Ratio Achievable in Ubicomp MANETs Using Location-Aware Transmission Strategies, CEET 2017

[53] M. Kaleem GALAMALI, Assoc. Prof Nawaz MOHAMUDALLY, Trend Analyses of Critical Values Obtained for Overall Fairness Ratio Achievable in Ubicomp MANETs Using Location-Aware Transmission Strategies, CEET 2017

[54] M. Kaleem GALAMALI, Assoc. Prof Nawaz MOHAMUDALLY, Trend Analyses of Critical Values Obtained for Energy Consumption Fairness Proportion Achievable in Ubicomp MANETs Using Location-Aware Transmission Strategies, ACCN 2017.

[55] M. Kaleem GALAMALI, Assoc. Prof Nawaz MOHAMUDALLY, Trend Analyses of Critical Values Obtained for Minimum Fairness Proportion Achievable in Ubicomp MANETs Using Location-Aware Transmission Strategies, ACCN 2017.

[56] M. Kaleem GALAMALI, Assoc. Prof Nawaz MOHAMUDALLY, Trend Analyses of Critical Values Obtained for Maximum Fairness Proportion Achievable in Ubicomp MANETs Using Location-Aware Transmission Strategies, ACCN 2017.

[57] M. Kaleem GALAMALI, Assoc. Prof Nawaz MOHAMUDALLY, Trend Analyses of Critical Values Obtained for Sender Fairness Proportion Achievable in Ubicomp MANETs Using Location-Aware Transmission Strategies, ACCN 2017.

[58] M. Kaleem GALAMALI, Assoc. Prof Nawaz MOHAMUDALLY, Trend Analyses of Critical Values Obtained for Packets Per Distance Achievable in Ubicomp MANETs Using Location-Aware Transmission Strategies, ACCN 2017.

[59] M. Kaleem GALAMALI, Assoc. Prof Nawaz MOHAMUDALLY, Trend Analyses of Critical Values Obtained for Maximum CBR Distance Achievable in Ubicomp MANETs Using Location-Aware Transmission Strategies, ACCN 2017.

[60] M. Kaleem GALAMALI, Assoc. Prof Nawaz MOHAMUDALLY, Trend Analyses of Critical Values Obtained for Minimum CBR Distance Achievable in Ubicomp MANETs Using Location-Aware Transmission Strategies, ACCN 2017.

[61] M. Kaleem GALAMALI, Assoc. Prof Nawaz MOHAMUDALLY, Trend Analyses of Critical Values Obtained for Range CBR Distance Achievable in Ubicomp MANETs Using Location-Aware Transmission Strategies, ACCN 2017.

[62] M. Kaleem GALAMALI, Assoc. Prof Nawaz MOHAMUDALLY, Extending Sender Node Battery Availability in Ubicomp with Location-Aware MANET Transmission, ACCN 2017.

[63] M. Kaleem GALAMALI, Assoc. Prof Nawaz MOHAMUDALLY, Extending Overall Node Battery Availability in Ubicomp with Location-Aware MANET Transmission, ACCN 2017.

[64] M. Kaleem GALAMALI, Assoc. Prof Nawaz MOHAMUDALLY, Extension of Sender Node Battery Extra Availability in Ubicomp with Location-Aware MANET Transmission Compared to Direct Node-To-Node
Transmission, ACCN 2017.

[65] M. Kaleem GALAMALI, Assoc. Prof Nawaz MOHAMUDALLY, Extension of Overall Node Battery Extra Availability in Ubicomp with Location-Aware MANET Transmission Compared to Direct Node-To-Node Transmission, ACCN 2017

[66] M. Kaleem GALAMALI, Assoc. Prof Nawaz MOHAMUDALLY, Methodology Formulation for Exact Location Tracking of Node Positions in Ubicomp MANETs Using NS2, ACCN 2017.

[67] M. Kaleem GALAMALI, Assoc. Prof Nawaz MOHAMUDALLY, Methodology of MANET Route Formulation and Tracking Nodes Energy Expenditure in Ubicomp MANETs Using NS2, ACCN 2017.

[68] M. Kaleem GALAMALI, Assoc. Prof Nawaz MOHAMUDALLY, Methodology of Processing MANET Routes for each Transmission Packet of a CBR in Ubicomp MANETs Using NS2, ACCN 2017.

[69] Mohammed Humayun Kabir, Syful Islam, Md. Javed Hossain, Sazzad Hossain, Detail Comparison of Network Simulators, International Journal of Scientific \& Engineering Research, Volume 5, Issue 10, October-2014

[70] Arun Gupta, Web site blog "http://arungupta.co.in/blog/?p=37", title "segmentation fault in NS-2, 24 $4^{\text {th }}$ June 2012, accessed on $13^{\text {th }}$ March 2014

About Author (s)

Associate Professor Nawaz Mohamudally works at University of Technology, Mauritius (UTM) and has undertaken supervision of $\mathrm{MPhil} / \mathrm{PhD}$ Students for many years.

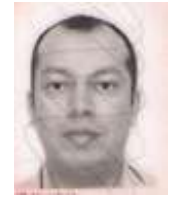

M. Kaleem Galamali is a part-time student (achieved M Phil Transfer on 28.10.2014, currently $\mathrm{PhD}$ student) at UTM under supervision of A.P. Nawaz Mohamudally. 